\title{
Phytochemical properties and heavy metal accumulation in wheat grain after three years' fertilization with biogas digestate and mineral waste
}

\author{
Krzysztof Różyło ${ }^{1}$, Michał Świeca², Urszula Gawlik-Dziki², Sylwia Andruszczak ${ }^{1}$, Ewa Kwiecińska-Poppe ${ }^{1}$, Piotr Kraska ${ }^{1}$ \\ ${ }^{1}$ Department of Agricultural Ecology, University of Life Sciences in Lublin, Akademicka Str. 13, PL-20-950 Lublin, Poland \\ 2 Department of Biochemistry and Food Chemistry, University of Life Sciences in Lublin, Poland \\ e-mail: krzysztof.rozylo@up.lublin
}

\begin{abstract}
Non-standard materials used for plant fertilization, require characterization to reduce any possible undesired effects. The aim of this study was to investigate the effect of fertilization with biogas digestate (BD) and mining waste (carboniferous mudstones (MS) from coal mine) on wheat yield quality and the bioaccumulation of heavy metals in wheat grains in relation to conventional fertilization (NPK) and no fertilization. Using the co-application of waste $(M S+B D)$, the highest yield was obtained in the first and second year, but in the third year, a slight decrease in yield was observed compared to NPK. In all years, BD and MS+BD fertilization increased the content of protein, wet gluten, and phenols in wheat grain compared to NPK and no fertilization. Waste fertilization had a positive effect on the antioxidant capacity index of grain but only in the first year. The bioaccumulation index (BAI) demonstrated that NPK decreased BAI for $\mathrm{Zn}, \mathrm{B}, \mathrm{Cd}$, and Mn, whereas MS+BD decreased BAl for $\mathrm{Cu}, \mathrm{Sr}, \mathrm{Pb}, \mathrm{Co}, \mathrm{Ba}$, and $\mathrm{Cr}$.
\end{abstract}

Key words: antioxidant capacity, grain quality, phenolics, flavonoids, nutritional value, protein, starch, gluten

\section{Introduction}

Environmental protection problems, especially challenges coming from enhanced recycling, result in attempts to use various organic and mineral wastes to fertilize plants and to improve soil properties. One of the methods used to increase efficiency in agriculture is the use of the residues produced in methanogenesis in biogas plants (biogas digestate - BD).

The research reveals that digestate improves the physical and chemical properties of the soil, increases yields, and decreases the nitrate content in plants compared to mineral fertilization. BD also increases the content of organic $\mathrm{C}$ in the soil and reduces the rate of its transformation in comparison to non-digested input organic materials (Chen et al. 2012, Johansen et al. 2013, Lopedota et al. 2013). BD contains more (60-70\% of total N) mineral nitrogen ( $\mathrm{NH}^{+} / \mathrm{NH}^{-}$) compared to different types of organic fertilizers (e.g., compost, cattle manure contains 6-30\% mineral N of total N) (Svensson et al. 2004, Alburquerque et al. 2012, Lopedota et al. 2013). Mineral nitrogen found in digestate occurs in readily available form to plants. When in available form, unused nitrogen can be leached or emitted from the soil and thus, it can be harmful to the environment. Nitrogen losses after fertilization with BD may be higher compared to other types of organic fertilizers, on the other side, these nitrogen losses may be similar to synthetic mineral fertilizers, especially in soils with low $\mathrm{N}$ retention (sorption). Efficient fertilization with BD should depend on its properties, and this means that it should be applied in small split doses adjusted to crop and soil requirements (Alburquerque et al. 2012, Lopedota et al. 2013). Depending on the feedstocks used for biogas production, BD can significantly differ in the content and proportions of macro- and micronutrients (Demirel et al. 2013, Różyło et al. 2015).

Clay rocks including mudstones represent another direction in the search for the increase in soil quality and agronomic yield. The basic problem in mining is the production of waste rocks; therefore, mines are interested in their dispersion into the environment of surrounding regions. Furthermore, a high dose addition of clay and mudstone (from different sources) to the soil is a procedure that can be undertaken only rarely. Not all waste rocks from the mining industry can be used for soil reclamation. For obvious reasons, waste that could have negative effects on the soil or plants cannot be used. Therefore, mining waste must be thoroughly tested before its addition to the soil. Clay rocks including mudstones possess a relatively high capacity for sorption of organic and inorganic compounds (Koutsopoulou et al. 2010, Jabłońska 2012). Their application to podzolic soil changes its structure as well as the distribution, size and density of pores; it changes soil aeration, water retention capacity, and increases the net soil surface area and nutrient retention. Depending on its composition, clay stone can increase the content of minerals and their bioavailability as a direct or indirect effect of pH change (Mader et al. 1997, Sudnitsyn 2015). 
An increase in the content and bioavailability of minerals for plants is of particular importance in reference to the issue of depleting the soil of micronutrients. This is translated into the overall soil yield potential. Clay minerals may also change the amount and the bioavailability of contaminants in the soil, including heavy metals. The mobility and bioavailability of cationic metals and anionic metalloids in soils are affected by soil amendments in different ways. To reduce the mobility and bioavailability of metals/metalloids in contaminated soils, several organic and inorganic soil amendments are described in literature. But, depending on the environmental conditions, increased mobilization of metalloids in these contaminated soils was often observed when they were treated with soil amendments (Violante et al. 2010, Lim et al. 2013).

Apart from providing major nutritional components, food should be a source of biologically active substances regulating physiological processes in the human organism (Zhao 2007, Świeca and Baraniak 2014). Wheat is one of the most popular sources of food and should have a high nutritional value. Wheat grown under appropriate conditions contains many macro- and micronutrients as well as phenolic acid compounds with well documented antioxidant activity (Okarter et al. 2010, Hung et al. 2011, Gawlik-Dziki et al. 2012). In response to changing environmental conditions and their adaptation to existing conditions, plants modify their metabolism and uptake of elements, including heavy metals and other contaminants. Therefore, the composition and quality of food of plant origin may also change (Zhao 2007, Świeca et al. 2012, Gawlik-Dziki et al. 2013).

Increasingly, agriculture faces the problem of soil degradation, reducing the quality of plant products. Growing plants under degraded soil conditions require the use of various treatments that may eliminate the negative effect on the quality of food products of disturbing the ion balance of the soil. Despite the increasing interest in the use of wastes for plant fertilization, there is a lack of comprehensive research on the effectiveness of this type of treatments and their effect on the nutritional and health-promoting value of cereals thus treated.

The main aim of the present study was to evaluate the effect of fertilization with biogas digestate and mining waste on wheat yield and the level of major nutrients in grain. Special attention was also paid to the nutritional (protein and starch) and nutraceutical potential (phenols and antioxidant activity). In addition, the study determined the effect of the studied factors on the degree of uptake and bioaccumulation of heavy metals in wheat grain.

\section{Materials and methods}

\section{Field experiment}

A field experiment was performedin the growing seasons 2013/2014, 2014/2015, and 2015/2016 at the Experimental Farm in Bezek (N: 51.200696 E: 23.293073), which belongs to the University of Life Sciences in Lublin (Poland). In 2013, the research work comprised preparing the field, setting up a field experiment, collecting soil samples, and starting preliminary analysis. The experiment was set up in a randomized block design in three replicates ( 5 treatments $\times 3$ replicates $=15$ plots each with an area of $37.5 \mathrm{~m}^{2}$ each) on podzolic soil (PS). The particle size distribution of PS was as follows: sand $(2.0-0.05 \mathrm{~mm})=72 \%$; coarse silt $(0.05-0.02 \mathrm{~mm})=14 \%$; fine silt $(0.02-$ $0.002 \mathrm{~mm})=13 \%$, and clay particle size $<0.002=1 \%$. The PS had a low content of total $\mathrm{N}, \mathrm{P}, \mathrm{K}$, and Mg (Table 1).

The podzolic soil was amended with BD and MS. Based on the following experimental design (Table 2), BD and MS were added (during autumn pre-sowing tillage operations on the depth $25 \pm 2 \mathrm{~cm}$ ).

Synthetic fertilizers in the conventional fertilization treatment and the waste materials were incorporated into the soil in the fall during the preparation of the field for sowing. The winter wheat cultivar "Tonacja" was sown on September 18-21, 2013, 2014, and 2015. Nitrogen fertilizer (urea) was applied in amide form (C- $\left.\mathrm{NH}_{2}\right)$ and was divided into two doses: one dose of $40 \mathrm{~kg} \mathrm{ha}^{-1}$ was applied in the fall (immediately after sowing), while the other one (80 $\mathrm{kg} \mathrm{ha}^{-1}$ ) in the spring at the beginning of plant growth. The basis for determining the rate of tested materials was not mainly $\mathrm{N}$, but also the high content of $\mathrm{K}, \mathrm{P}, \mathrm{Mg}$, Na in $\mathrm{BD}$ and $\mathrm{Al}, \mathrm{Fe}, \mathrm{Na}, \mathrm{K}$ in MS (Table 1). The amount of mining waste was based on the assumption that $5 \%$ (mass of MS to mass of soil) is the minimum to obtain noticeable changes in soil properties and their effects on plants (Różyło et al. 2016). The field experiment scheme from the first vegetative season (2013/2014) was repeated in the two subsequent seasons (2014/2015 and 2015/2016) to determine the influence of subsequent doses of wastes on the yield and quality of wheat (Table 2). The plots were at the same site (blocks) in the crop rotation: winter oilseed rape - winter wheat - oats. Annual NPK applications were: $\mathrm{TN}=147 ; \mathrm{P}=29 ; \mathrm{K}=137 \mathrm{~kg} \mathrm{ha}^{-1}$ from $\mathrm{BD}$ and $\mathrm{TN}=558 ; \mathrm{P}=2.3 ; \mathrm{K}=51 \mathrm{~kg} \mathrm{ha}^{-1}$ from $\mathrm{MS}$. The very high $\mathrm{C} / \mathrm{N}$ ratio for MS (77.4) indicates that despite high levels of $\mathrm{TN}$, it was not available to plants. 
Table 1. Chemical properties of control soil (podzolic soil - PS), biogas digestate (BD) and mining waste (mudstone - MS) used in the experiment (Różyło et al. 2015) (mean \pm SD, $n=3$ )

\begin{tabular}{cccc}
\hline $\begin{array}{c}\text { Parameters and } \\
\text { elements }\end{array}$ & PS & BD & MS \\
\hline dry matter (\%) & - & $8-9$ & $75-80$ \\
$\mathrm{pH}($ in $1 \mathrm{M} \mathrm{KCl})$ & $4.4 \pm 0.23$ & $9.9 \pm 0.47$ & $7.8 \pm 0.31$ \\
$\mathrm{C} / \mathrm{N}$ & 23.8 & 22.0 & 77.4 \\
$\mathrm{EC} \mathrm{(mS/cm)}$ & $1.20 \pm 0.17$ & $3.70 \pm 0.25$ & $0.84 \pm 0.19$ \\
$\mathrm{mg} \mathrm{kg}{ }^{-1} \mathrm{DW}$ & & & \\
\hline $\mathrm{TOC}$ & $9506 \pm 781$ & $633027 \pm 1891$ & $281195 \pm 3180$ \\
$\mathrm{TN}$ & $413 \pm 89$ & $28820 \pm 118$ & $3631 \pm 177$ \\
$\mathrm{P}$ & $49 \pm 4.8$ & $5580 \pm 29.4$ & $14 \pm 27.1$ \\
$\mathrm{~K}$ & $45 \pm 3.5$ & $26906 \pm 39.8$ & $333 \pm 11.9$ \\
$\mathrm{Mg}$ & $10 \pm 0.7$ & $4420 \pm 30.4$ & $4200 \pm 24.3$ \\
$\mathrm{Fe}$ & $393 \pm 12.9$ & $1445 \pm 19.6$ & $761 \pm 37.1$ \\
$\mathrm{Ca}$ & $222 \pm 18.5$ & $311 \pm 27.3$ & $1450 \pm 40.6$ \\
$\mathrm{Na}$ & $603 \pm 29.4$ & $2900 \pm 38.9$ & $132 \pm 1.5$ \\
$\mathrm{~S}-\mathrm{SO}$ & $8 \pm 0.8$ & $225 \pm 2.3$ & $10.1 \pm 0.09$ \\
$\mathrm{~B}$ & $0.5 \pm 0.04$ & $23.4 \pm 0.15$ & $96 \pm 5.1$ \\
$\mathrm{Mn}$ & $61 \pm 4.5$ & $246 \pm 6.9$ & $14.6 \pm 0.16$ \\
$\mathrm{Cu}$ & $0.5 \pm 0.04$ & $14.2 \pm 0.12$ & $24.4 \pm 0.7$ \\
$\mathrm{Zn}$ & $2.5 \pm 0.2$ & $145.1 \pm 0.4$ & $20870 \pm 87.3$ \\
$\mathrm{Al}$ & $4505 \pm 52.5$ & $512 \pm 45.2$ & \\
\hline & & &
\end{tabular}

$\mathrm{EC}=$ electrical conductivity; $\mathrm{DW}=$ dry weight; $\mathrm{TOC}=$ total organic carbon; $\mathrm{TN}=$ total nitrogen; $\mathrm{C} / \mathrm{N}=$ ratio of carbon to nitrogen; $\mathrm{P}, \mathrm{K}$, $\mathrm{Mg}$ - (available $\mathrm{P}$ and $\mathrm{K}$ were determined by the Egner-Riehm method; and, available $\mathrm{Mg}$ - by the atomic absorption spectrometry (AAS) method after extraction with $0.0125 \mathrm{~mol} \mathrm{l}^{-1} \mathrm{CaCl}_{2}$

Table 2. Experimental design

\begin{tabular}{|c|c|c|c|}
\hline \multirow{2}{*}{$\begin{array}{l}\text { Experimental } \\
\text { factors }\end{array}$} & \multicolumn{3}{|c|}{ Years (growing seasons) } \\
\hline & $2013 / 2014$ & $2014 / 2015$ & $2015 / 2016$ \\
\hline C & & 0 (control soil) & \\
\hline NPK & NPK & NPK & NPK \\
\hline MS & MS (155 t DW ha-1) & MS (155 t DW ha-1) & MS (155 t DW ha-1) \\
\hline $\mathrm{BD}$ & $\mathrm{BD}\left(5.1 \mathrm{t} \mathrm{DW} \mathrm{ha}^{-1}\right)$ & $\mathrm{BD}\left(5.1 \mathrm{t} \mathrm{DW} \mathrm{ha}^{-1}\right)$ & $\mathrm{BD}\left(5.1 \mathrm{t} \mathrm{DW} \mathrm{ha}^{-1}\right)$ \\
\hline$M S+B D$ & $\begin{array}{c}\text { MS+BD }\left(155 \mathrm{t} \mathrm{DW} \mathrm{ha}^{-1}+5.1 \mathrm{t}\right. \\
\text { DW ha-1) }\end{array}$ & $\begin{array}{c}\text { MS+BD }\left(155 \mathrm{t} \mathrm{DW} \mathrm{ha}^{-1}+5.1 \mathrm{t}\right. \\
\mathrm{DW} \mathrm{ha-1)}\end{array}$ & $\begin{array}{c}\mathrm{MS}+\mathrm{BD}\left(155 \mathrm{t} \mathrm{DW} \mathrm{ha}^{-1}+5.1 \mathrm{t}\right. \\
\mathrm{DW} \mathrm{ha-1})\end{array}$ \\
\hline
\end{tabular}

\section{Characteristics of waste materials}

Biogas digestate (BD) was collected from a biogas plant operated byWikana Bioenergia Sp. z o.o. (Poland). The following feedstocks were used for energy production: corn silage (70\%), sugar bagasse beet (15\%), fruit pomace $(5 \%)$, dairy wastes $(5 \%)$, and manure $(5 \%)$. The type of fermentation wasmesophilic $\left(32-42^{\circ} \mathrm{C}\right)$. This waste is a mixture of water and digested organic matter. The dry matter content in unprocessed BD used in the study was $8-9 \%$ (Różyło et al. 2015). In the subsequent years, BD originated from the same biogas plant, with the substrates for the biogas production from the same suppliers. Moreover, the proportions of substrates and fermentation conditions did not change significantly, which enabled the use of $\mathrm{BD}$ with similar parameters in the subsequent years.

The source of clay minerals was mudstones (MS) originating from carboniferous roof rocks, bottom rocks, or interlayers of exploited coal seams in a coal mine belonging to the coal company "Bogdanka" SA (Poland). 
In petrographic terms, it is a mixture of mainly clays and mudstones. The mechanical composition of carboniferous mudstones (MS) is: fraction 120-200 mm = about 10\%, fraction $120-20 \mathrm{~mm}=30-40 \%$, fraction $20-0.5 \mathrm{~mm}$ $=30-40 \%$, and fraction $<0.5 \mathrm{~mm}=$ about $20 \%$. Stony fractions $(200-1 \mathrm{~mm}$ ) disintegrate under atmospheric conditions relatively quickly (few months); therefore, these wastes do not require mechanical treatment prior to application to the soil. These minerals complement organic matter concentrations. The mineral composition of this waste primarily consists of silica $\left(\mathrm{SiO}_{2}=470 \mathrm{~g} \mathrm{~kg}^{-1}\right)$ and aluminum oxide $\left(\mathrm{Al}_{2} \mathrm{O}_{3}=220 \mathrm{~g} \mathrm{~kg}^{-1}\right)$ (Różyło et al. 2015). In all years, the same MS was used, which was shipped prior to the establishment of the field experiment, stored under cover, and each year, a suitable portion was transported to the field. Table 1 shows the properties of the waste materials used in the experiment.

\section{Soil and waste analysis}

First soil samples were collected in 2013 immediately before the start of the experiment (Table 1). Subsamples were collected from the entire length of the arable layer of the soil $(27 \pm 2 \mathrm{~cm})$ with a stainless steel corer $(2 \mathrm{~cm}$ in diameter). Then, the subsamples from each plot were mixed to obtain a representative sample. The following soil properties were analyzed using Van Reeuwijk's standard laboratory procedures: particle size distribution by the hydrometer method; $\mathrm{pH}$ in $1 \mathrm{M} \mathrm{KCl}$ solution potentiometrically (a soil to solution ratio of 1:2.5); total nitrogen was determined by Kjeldahl's method without the application of Devarda's alloy (Cu-Al-Zn alloy reducer of nitrites and nitrates).

The total organic carbon (TOC) content was determined by the gravimetric method. The soil/BD/MS was dried at a temperature of $105^{\circ} \mathrm{C}$ to constant weight and then incinerated at $550{ }^{\circ} \mathrm{C}$ and the weight loss was measured. The concentration of plant available $\mathrm{P}$ and $\mathrm{K}$ were determined by the Egner-Riehm method (KQ/PB-07); and, available $\mathrm{Mg}$ - by the atomic absorption spectrometry (AAS) method after extraction with $0.0125 \mathrm{~mol} \mathrm{l}^{-1} \mathrm{CaCl}_{2}(\mathrm{PN}-\mathrm{R}-$ 04020, 1994).

Waste and the majority of conventional fertilization were applied in the autumn of the preceding year prior to sowing of winter wheat. Due to the required homogenization time of waste with soil, the soil samples for the measurement of heavy metal content were collected in spring (2014 and 2016) prior to the commencement of winter wheat vegetation.

The metal and other elemental concentrations were determined using a START D microwave oven (Milestone, Italy) via a wet method in a mixture of nitric acid $(8 \mathrm{ml})$ and hydrochloric acid $(2 \mathrm{ml})$. Analysis of the $\mathrm{Cr}, \mathrm{Cu}, \mathrm{Ni}, \mathrm{Mn}$, $\mathrm{Pb}, \mathrm{Cd}, \mathrm{Zn}, \mathrm{Co}, \mathrm{Fe}, \mathrm{Ba}, \mathrm{Al}, \mathrm{Sr}$ and Ag contents was performedusing ICP-OES (Thermo Scientific, ICAP 7000 Series, USA). Evaluation of the accuracy and precision of the analytical procedures used reference materials (Heavy Clay Soil, RTH 953. Promochem). Based on the total contents of elements in the soil and grain, the Bioaccumulation Index (BAI) was calculated according to the following formula: BAIx=GCx/SCx (x-element; $\mathrm{GC}$-total concentration in grain; SC-total concentration in soil).

\section{Yield analysis}

Each year when wheat grains were ready to be harvested, whole winter wheat plants (stubble $10 \mathrm{~cm}$ left in the field) were sampled by hand from three randomly selected locations with an area of $1 \mathrm{~m}^{2}$. Ears were separated from straw manually. Ear samples were threshed in a WINTERSTEIGER LD 180 laboratory thresher. Grain and crop residues were weighed separately, converting their yields to a per hectare basis and calculated harvest index (HI $=$ grains $/$ residues + grains). Next, 500 grams of the samples were separated for qualitative evaluation. Thousand grains weight was determined (counting $2 \times 500$ grains).

\section{Analysis of nutritional and health-promoting quality of wheat grain}

The grain samples were analyzed for their protein, wet gluten and starch contents, separately for each replicate/ plot and the 3 sampling sites $\left(1 \mathrm{~m}^{2}\right)$. Total protein (TP) was calculated from the total nitrogen content (in the rate of $N$ - 5.7). The total nitrogen (TN) content was determined for the whole milled grains (whole wheat flour) by Kjeldahl method (ISO/TS 16634-2:2009). The amount of wet gluten was determined by mechanical means (ISO 21415-2:2015). The starch content was determined by Clendenning method (ICC Standard no. 122/1). These data were the basis for calibration "OmegAnalizer G" produced by Bruins Instruments NIR (near infrared) grain analyzers. Wavelength range is $730-1100 \mathrm{~nm}$ transmission with $5 \mathrm{~nm}$ scan increment. Automatic feed with multiple sub-sample measurements allowed to get repeatable results for the tested grain parameters. 
Phenols and antioxidants were isolated from wheat flours $(0.5 \mathrm{~g})$ by extracting three times with $4 \mathrm{ml}$ of acetone/ water/hydrochloric acid (70:29:1, v/v/v). After centrifugation (10 min, $6800 \times \mathrm{g}$ ) fractions were collected, combined, and used for further analysis.

Total phenols content (TPC) were estimated according to the Folin-Ciocalteau method. A $0.5 \mathrm{ml}$ sample of the extract was mixed with $0.5 \mathrm{ml}$ of $\mathrm{H}_{2} \mathrm{O}, 2 \mathrm{ml}$ of Folin reagent $\left(1: 5 \mathrm{H}_{2} \mathrm{O}\right)$, and after 3 minutes with $10 \mathrm{ml}$ of $10 \% \mathrm{Na}_{2} \mathrm{CO}_{3}$. After 30 minutes, the absorbance of mixed samples was measured at a wavelength of $720 \mathrm{~nm}$. The amount of total phenolics was expressed as a gallic acid equivalent (GAE) per g of dry weight (DW).

Total flavonoids content (TFC) were estimated according to the method described by Bahorun et al. (2004). One milliliter of sample was mixed with $1 \mathrm{ml} 2 \% \mathrm{AlCl}_{3} \times 6 \mathrm{H}_{2} \mathrm{O}$. After $10 \mathrm{~min}$ absorbance at $430 \mathrm{~nm}$ was measured. The total flavonoid content was expressed as quercetin equivalent (QE) in milligrams per DW.

Antiradical activity was performed using an improved ABTS decolorization assay (Re et al. 1999). The ABTS radical cation as produced by reacting $7 \mathrm{mM}$ of ABTS stock solution with $2.45 \mathrm{mM}$ potassium persulfate (final concentration) and allowing the mixture to stand in the dark for at least $6 \mathrm{~h}$ at room temperature prior to use. The ABTS solution was diluted to an absorbance of $0.7 \pm 0.05$ at $734 \mathrm{~nm}$ (Lambda 40 UV-Vis spectrophotometer, Perkin Elmer). The affinity of the test material to quench the ABTS free radical was evaluated according to the following equation: scavenging $\%=\left(\left[A_{C}-A_{A}\right] / A_{C}\right) \times 100$, where : $A_{C}$ - absorbance of control, $A_{A}$ - absorbance of sample.

Free radical scavenging ability was expressed as Trolox equivalent (TE) in micromoles per gram of DW.

The reducing power (RP) was determined by the method of Oyaizu (1986). The analyzed sample (2.5 ml) was mixed with phosphate buffer $(2.5 \mathrm{ml}, 200 \mathrm{mM}, \mathrm{pH} 6.6)$ and potassium ferricyanide $\left.\mathrm{K}_{3}\left(\mathrm{Fe}_{\mathrm{CN}}\right]\right)(2.5 \mathrm{ml}, 1 \%)$. The mixture was incubated at $50{ }^{\circ} \mathrm{C}$ for $20 \mathrm{~min}$. Reactions were stopped with $0.5 \mathrm{ml} 10 \%$ TCA and centrifuging for $10 \mathrm{~min}$ at $6500 \mathrm{~g}$. The upper layer of the solution $(2.5 \mathrm{ml})$ was mixed with distilled water $(2.5 \mathrm{ml})$ and $0.5 \mathrm{ml}$ of $0.1 \% \mathrm{FeCl}_{3}$ and the absorbance was measured at $700 \mathrm{~nm}$. RP was expressed as Trolox equivalent in micromoles per gram of DW.

Chelating power (CP) was determined by the method of Guo et al. (2001). The extract samples (5 ml) were added to $0.1 \mathrm{ml}$ of $2 \mathrm{mM} \mathrm{FeCl}_{2}$ solution and $0.2 \mathrm{ml} 5 \mathrm{mM}$ ferrozine. The mixture was shaken vigorously and left to stand at room temperature for $10 \mathrm{~min}$. Then, the absorbance of the solution was measured spectrophotometrically at $562 \mathrm{~nm}$. The percentage of inhibition of ferrozine-Fe ${ }^{2+}$ complex formation was calculated according to the following formula: \% inhibition $=\left[1-\left(A_{p} / A_{c}\right)\right] \times 100$, where: $A c-$ absorbance of control, $A p-$ absorbance of sample. CP was expressed as ethylenediaminetetraacetic acid (EDTA) equivalent in micrograms per gram of DW.

Three complementary antioxidant methods were integrated to obtain the total antioxidant capacity index (ACI) (Świeca and Baraniak 2014). The index may be useful for evaluation of the total antioxidant potential of wheats from different fertilization with respect to control. The $\mathrm{ACl}$ was calculated as the sum of relative activities (RA) for each antioxidant chemical method divided by the number of methods $(n) . A C l=\Sigma R A_{(n)} / n$

RA was calculated as follows: $\mathrm{RA}=\mathrm{Ax} / \mathrm{Ac}$, where: $\mathrm{Ax}=$ activity of modified sprouts for the method and $\mathrm{Ac}=\mathrm{activ}-$ ity of control sprouts determined for the method.

\section{Statistical analysis}

All experimental results were presented as means of three parallel replicates. One-way analysis of variance (ANOVA) and Tukey's post hoc test were used to comparè groups within different elicitors. $\alpha$ values $<0.05$ were regarded as significant. Tukey's HSD test (intermediate between LSD test and Scheffe's test) is an easy method of determining the critical significance of differences and is adequate in simple factor systems (equal sample sizes per group).

\section{Results}

\section{Yield structure and nutrient content}

The incorporation of wastes into the tested soil (PS) significantly changed the winter wheat yield accumulation or above-ground biomass (crop residues) accumulation. In all years the coapplication of wastes (MS+BD) increased the wheat grain yield compared to controls (significant differences) and in 2015 compared to NPK (Table 3). In the third year, the fertilization with MS+BD resulted in a non-significant decrease in wheat grain yield compared to NPK. 
The highest grain yield was obtained in the second year on soil fertilized with MS+BD. The highest straw and other harvest residue weight was observed on those plots with NPK fertilization. Moreover, a significantly better harvest index (HI) was obtained by fertilizing with MS+BD and with MS alone when compared to the control (C), NPK, and BD. The subsequent doses of MS+BD in the following years led to a deterioration in the HI. In the first and third year, MS+BD significantly increased thousand grains weight (TGW) compared to other fertilization methods. In the second year, MS+BD significantly increased TGW only in comparison to $C$.

Table 3. Effect of biogas digestate (BD) and mining waste (mudstones $-\mathrm{MS}$ ) on the yield of winter wheat (mean, $\mathrm{n}=3$ )

\begin{tabular}{|c|c|c|c|c|c|c|}
\hline \multirow[t]{2}{*}{ Parameters } & \multirow[t]{2}{*}{ Years } & \multicolumn{5}{|c|}{ Type of fertilization } \\
\hline & & $\mathrm{C}$ & NPK & MS & $B D$ & $\mathrm{MS}+\mathrm{BD}$ \\
\hline \multirow{3}{*}{$\begin{array}{l}\text { grain yield } \\
\left(\mathrm{t} \mathrm{ha}^{-1}\right)\end{array}$} & 2014 & $2.17^{\mathrm{a}}$ & $3.43^{c}$ & $2.73^{b}$ & $2.97^{b}$ & $3.85^{c}$ \\
\hline & 2015 & $2.53^{a}$ & $3.76^{\mathrm{b}}$ & $3.25^{b}$ & $3.12^{\mathrm{ab}}$ & $4.17^{c}$ \\
\hline & 2016 & $2.94^{\mathrm{a}}$ & $3.98^{b}$ & $3.08^{a}$ & $3.35^{\mathrm{a}}$ & $3.82^{b}$ \\
\hline \multirow{3}{*}{$\begin{array}{l}\text { harvest residues } \\
\left(\mathrm{t} \mathrm{ha}^{-1}\right)\end{array}$} & 2014 & $4.16^{\mathrm{ab}}$ & $6.28^{d}$ & $3.90^{\mathrm{a}}$ & $5.45^{c}$ & $4.91^{b c}$ \\
\hline & 2015 & $4.78^{a}$ & $6.32^{c}$ & $4.78^{\mathrm{a}}$ & $5.62^{b}$ & $5.96^{b c}$ \\
\hline & 2016 & $4.97^{a}$ & $6.67^{c}$ & $4.28^{\mathrm{a}}$ & $6.00^{b}$ & $5.89^{b}$ \\
\hline \multirow[t]{3}{*}{ harvest index $-\mathrm{HI}$} & 2014 & $0.34^{b}$ & $0.35^{b}$ & $0.41^{\mathrm{a}}$ & $0.35^{b}$ & $0.43^{\mathrm{a}}$ \\
\hline & 2015 & $0.35^{b}$ & $0.37^{\mathrm{ab}}$ & $0.40^{\mathrm{a}}$ & $0.36^{b}$ & $0.41^{\mathrm{a}}$ \\
\hline & 2016 & $0.37^{\mathrm{ab}}$ & $0.37^{\mathrm{ab}}$ & $0.42^{\mathrm{a}}$ & $0.36^{b}$ & $0.39^{\mathrm{ab}}$ \\
\hline \multirow{3}{*}{$\begin{array}{l}\text { thousand grain weight } \\
\text { (TGW) } \\
\text { (g) }\end{array}$} & 2014 & $35.1^{\mathrm{a}}$ & $36.6^{\mathrm{a}}$ & $35.7^{\mathrm{a}}$ & $35.9^{a}$ & $39.8^{b}$ \\
\hline & 2015 & $37.8^{\mathrm{a}}$ & $39.3^{b}$ & $40.1^{b}$ & $39.7^{b}$ & $40.5^{b}$ \\
\hline & 2016 & $39.1^{a}$ & $40.6^{a}$ & $39.8^{a}$ & $40.2^{a}$ & $42.7^{b}$ \\
\hline
\end{tabular}

The most efficient in terms of the total protein and wet gluten content in the wheat grain were BD (in the first year) and MS+BD (in the second and third year) fertilizations. Digestate significantly increased the content of protein and gluten compared to C, NPK, and MS. In the second and third year, the MS+BD fertilization significantly increased the protein and gluten content compared to $C$ and MS. Moreover, the use of MS+BD fertilization efficiently increased the protein and wet gluten content in the subsequent years (Fig. 1).

The experimental factors in the first and third year didn't have a statistically proven effect on the starch content in the studied wheat grain. In the second year, a significant decrease in the starch content was recorded in the wheat grain fertilized conventionally (NPK) compared to that with no fertilization (C) or waste fertilization (MS, BD, MS+BD) (Fig. 1).

\section{Phenolics, flavonoids and antioxidant potential}

In the first year, a significant increase in the phenolic content (PC) in the wheat grain was obtained on those plots fertilized with digestate ( $\left.4.89 \mathrm{mg} \mathrm{g}^{-1} \mathrm{DW}\right)$ and with MS+BD (4.71 $\left.\mathrm{mg} \mathrm{g}^{-1} \mathrm{DW}\right)$ compared to C, NPK, and MS (Table 4). Similar relationships occurred in the second year, yet the differences were not statistically significant. In the third year, all combinations of waste fertilization significantly increased the PC compared to C and NPK. The experimental factors determined the flavonoid content (FC) in the wheat grain differently than PC, as in the first season, a significantly higher FC was obtained using NPK and MS compared to C, BD, and MS+BD. In the second and third year, the statistically highest FC characterized grain from BD fertilized plots (compared to $C, M S+B D$ in the second year and compared to C, MS and BD+MS in the third year) (Table 4). 


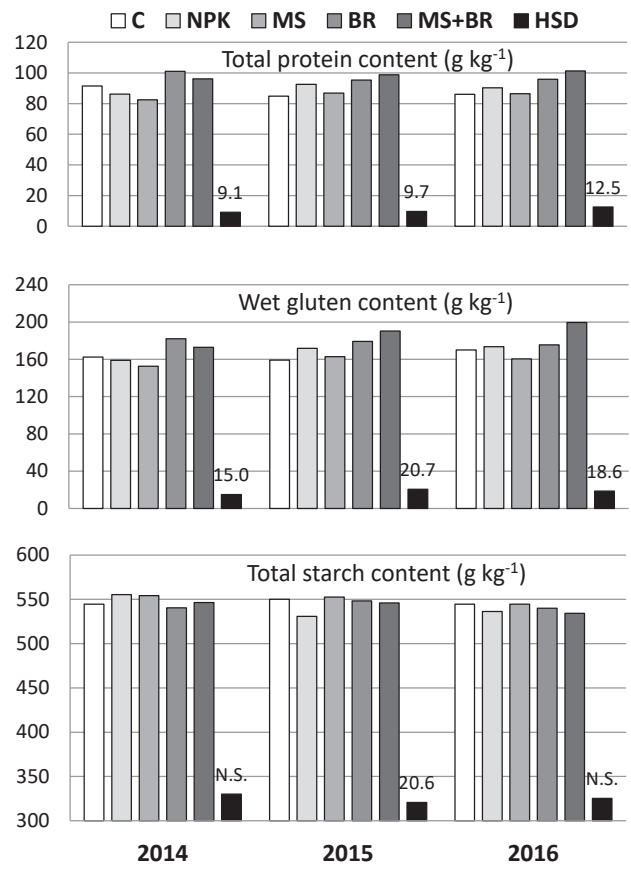

Fig. 1. Effect of biogas digestate $(B D)$ and mining waste (mudstones -MS) on the protein, gluten and starch contents of winter wheat grain $(n=3) ; C=$ control (podzolic soil $-P S$ without fertilization); NPK = PS + N, P, K, Mg, Ca, S (120 N, 100 $\mathrm{P}_{2} \mathrm{O}_{5}, 120 \mathrm{~K}_{2} \mathrm{O}, 40 \mathrm{MgO}, 60 \mathrm{Ca}, 30 \mathrm{SO}_{2} \mathrm{~kg} \mathrm{ha}^{-1}$, respectively); $M S=P S+155 t$ DW of MS ha-1; BD = PS + 5.1 t DW of BD ha ${ }^{1} ; \mathrm{MS}+\mathrm{BD}=\mathrm{PS}+155 \mathrm{t} \mathrm{DW}$ of $\mathrm{MS} \mathrm{ha} \mathrm{A}^{-1}+5.1 \mathrm{t} \mathrm{DW}$ of BD ha-1; $\mathrm{HSD}_{0.05}$ - honestly significant difference (Tukey's Test)

Table 4. Effect of biogas digestate (BD) and mining waste (MS) on the phenolics content and on the antioxidant capacity of winter wheat grain (mean, $n=3$ )

\begin{tabular}{|c|c|c|c|c|c|c|}
\hline \multirow[t]{2}{*}{ Parameters } & \multirow[t]{2}{*}{ Year } & \multicolumn{5}{|c|}{ Type of fertilization } \\
\hline & & C & NPK & MS & $\mathrm{BD}$ & $\mathrm{MS}+\mathrm{BD}$ \\
\hline \multirow{3}{*}{$\begin{array}{l}\text { phenolics content (PC) } \\
\left.\text { (mg GAE g }{ }^{-1} \mathrm{DW}\right)\end{array}$} & 2014 & $4.35^{b}$ & $4.20^{\mathrm{a}}$ & $4.22^{\mathrm{ab}}$ & $4.89^{d}$ & $4.71^{c}$ \\
\hline & 2015 & $4.11^{\mathrm{a}}$ & $4.29^{a}$ & $4.30^{\mathrm{a}}$ & $4.57^{\mathrm{a}}$ & $4.50^{\mathrm{a}}$ \\
\hline & 2016 & $3.82^{\mathrm{a}}$ & $4.05^{\mathrm{a}}$ & $4.81^{c}$ & $4.44^{b}$ & $4.57^{\mathrm{bc}}$ \\
\hline \multirow{3}{*}{$\begin{array}{l}\text { flavonoids content (FC) } \\
\text { (mg QE g-1 DW) }\end{array}$} & 2014 & $0.53^{b}$ & $0.59^{c}$ & $0.57^{b c}$ & $0.53^{b}$ & $0.47^{a}$ \\
\hline & 2015 & $0.50^{\mathrm{a}}$ & $0.58^{\mathrm{ab}}$ & $0.59^{b}$ & $0.60^{b}$ & $0.51^{\mathrm{a}}$ \\
\hline & 2016 & $0.47^{\mathrm{ab}}$ & $0.49^{\mathrm{bc}}$ & $0.43^{\mathrm{ab}}$ & $0.57^{c}$ & $0.40^{\mathrm{a}}$ \\
\hline \multirow{3}{*}{$\begin{array}{l}\text { chelating power }(\mathrm{ChP}) \\
\left(\mu \mathrm{g} \text { of EDTA } \mathrm{g}^{-1} \mathrm{DW}\right)^{*}\end{array}$} & 2014 & $88.5^{b}$ & $74.7^{a}$ & $84.3^{b}$ & $85.4^{b}$ & $85.0^{\mathrm{b}}$ \\
\hline & 2015 & $90.6^{a}$ & $86.4^{\mathrm{a}}$ & $98.9^{b}$ & $97.6^{b}$ & $89.8^{a}$ \\
\hline & 2016 & $76.2^{\mathrm{ab}}$ & $103.7^{c}$ & $91.0^{\mathrm{bc}}$ & $83.2^{\mathrm{ab}}$ & $69.7^{\mathrm{a}}$ \\
\hline \multirow{3}{*}{$\begin{array}{l}\text { reducing power (RP) } \\
\left(\mu \mathrm{mol} \text { of } T E \mathrm{~g}^{-1} \mathrm{DW}\right)\end{array}$} & 2014 & $1.68^{\mathrm{a}}$ & $1.89^{b}$ & $1.86^{b}$ & $2.01^{c}$ & $1.82^{\mathrm{b}}$ \\
\hline & 2015 & $1.70^{\mathrm{a}}$ & $1.97^{b}$ & $1.94^{\mathrm{ab}}$ & $2.18^{b}$ & $2.13^{\mathrm{b}}$ \\
\hline & 2016 & $1.52^{\mathrm{a}}$ & $1.58^{\mathrm{a}}$ & $1.81^{\mathrm{a}}$ & $1.68^{\mathrm{a}}$ & $2.34^{b}$ \\
\hline \multirow{3}{*}{$\begin{array}{l}\text { antiradical activity (ABTS) } \\
\left(\mu \mathrm{mol} \text { of TE } \mathrm{g}^{-1} \mathrm{DW}\right)\end{array}$} & 2014 & $0.93^{\mathrm{a}}$ & $0.97^{a}$ & $1.19^{a}$ & $2.63^{c}$ & $1.95^{\mathrm{b}}$ \\
\hline & 2015 & $1.31^{\mathrm{a}}$ & $1.40^{\mathrm{a}}$ & $1.40^{\mathrm{a}}$ & $1.94^{b}$ & $1.82^{\mathrm{b}}$ \\
\hline & 2016 & $1.45^{\mathrm{a}}$ & $1.24^{\mathrm{a}}$ & $1.87^{b}$ & $1.62^{\mathrm{ab}}$ & $1.54^{\mathrm{ab}}$ \\
\hline \multirow{3}{*}{$\begin{array}{l}\sum \text { total antioxidant } \\
\text { capacity index }(\mathrm{ACl})\end{array}$} & 2014 & - & 1.01 & 1.11 & 1.66 & 1.38 \\
\hline & 2015 & - & 1.06 & 1.10 & 1.28 & 1.21 \\
\hline & 2016 & - & 1.08 & 1.20 & 1.11 & 1.17 \\
\hline
\end{tabular}

$\mathrm{C}=$ control (podzolic soil $-\mathrm{PS}$ without fertilization); $\mathrm{NPK}=\mathrm{PS}+\mathrm{N}, \mathrm{P}, \mathrm{K}, \mathrm{Mg}, \mathrm{Ca}, \mathrm{S}\left(120 \mathrm{~N}, 100 \mathrm{P}_{2} \mathrm{O}_{5}, 120 \mathrm{~K} \mathrm{O}_{2}, 40 \mathrm{MgO}, 60\right.$ $\mathrm{Ca}, 30 \mathrm{SO}_{2} \mathrm{~kg} \mathrm{ha}^{-1}$, respectively); MS = PS $+155 \mathrm{t} \mathrm{DW}$ of $\mathrm{MS} \mathrm{ha}^{-1} ; \mathrm{BD}=\mathrm{PS}+5.1 \mathrm{t}$ DW of $\mathrm{BD}$ ha- ${ }^{-1} ; \mathrm{MS}+\mathrm{BD}=\mathrm{PS}+155 \mathrm{t}$ DW of $\mathrm{MS} \mathrm{ha}^{-1}+5.1$ t DW of $\mathrm{BD} \mathrm{ha}{ }^{-1} ; \mathrm{QE}=$ quercetin equivalent; $\mathrm{GAE}$ = gallic acid equivalent; $\mathrm{TE}$ = trolox equivalent; $\mathrm{EDTA}=$ ethylenediaminetetraacetic acid; DW = dry weight; a, b, c - data marked with the same letters do not differ significantly 
Table 4 demonstrates that experimental factors significantly influenced the parameters linked to the antioxidant characters of the grain (chelating power, reducing power, antiradical activity), yet they did not possess a directional character in any of the seasons. Thus, the total antioxidant capacity index (ACl) was calculated based on these parameters. The $\mathrm{ACl}$ calculation demonstrated that the best fertilization method was BD in the first and second year. In the third year, the highest $\mathrm{ACl}$ was noticed for MS.

\section{Heavy metal contents and bioaccumulation index (BAI)}

Tables S1 and S2 demonstrate that the content of toxic heavy metals in wheat grain as well as in the soil did not exceed the international permissible limits for heavy metals in soil and plants (in reference to WHO [1996]), following Ogundele et al. (2015) and Nazir et al. (2015) as well as with reference to EU Commission regulation No. 1275/2013 of 6-FAOLex) (EU 2013), even after the use of the third dose of waste in the third year of wheat cultivation. The content of elements in soil and grain of wheat had no clear differences related to the type of fertilization (2014 and 2016) and these results were difficult to interpret (Table S2). Therefore, the BAI was calculated by dividing the total content of heavy metals in wheat grain by the total content of heavy metals in the soil. A higher BAl value means a greater accumulation of metals in wheat grains (Table 5 ). $\mathrm{Zn}$ and $\mathrm{Cu}$, whose concentrations in grain were significantly higher thanthose in the soil, were the elements that were most accumulated. In 2014, the highest BAI for Zn occurred on those plots without fertilization and with fertilization with MS+BD, whereas in 2016, it was for those plots fertilized with MS and BD. In both 2014 and 2016, the highest BAI for Cu occurred on plots without fertilization and with fertilization with $\mathrm{BD}$. In both years, conventional fertilization in comparison to no fertilization or waste fertilization decreased the BAI for $\mathrm{Zn}, \mathrm{B}, \mathrm{Cd}$, and $\mathrm{Mn}$. Compared to the remaining fertilization methods, the first dose of MS+BD (in 2014) caused a decrease in BAl for $\mathrm{Cu}, \mathrm{Sr}, \mathrm{Pb}, \mathrm{Co}, \mathrm{Ba}, \mathrm{Al}$, and $\mathrm{Cr}$. In 2016, similar relationships were observed (after three years of using MS+BD) when the elements with the lowest $\mathrm{BAI}$ in reference to 2014 included B and excluded Al.

The mean BAI for all elements demonstrates that in 2014, the lowest accumulation of elements occurred on the conventionally fertilized plots, while it was the highest on the plots without fertilization. In 2016, the lowest accumulation of elements occurred on the plots fertilized with MS+BD and the highest on the plots fertilized with BD (Table 5).

Table 5. Microelements Bioaccumulation Index (BAI) calculated according to the following formula: $\mathrm{BAI}_{\mathrm{x}}=\mathrm{GC}_{\mathrm{x}} /$ $\mathrm{SC}_{\mathrm{x}}$ (x-element; GC-total concentration in grain; SC-total concentration in soil) $(\mathrm{n}=3)$

\begin{tabular}{|c|c|c|c|c|c|c|c|c|c|c|}
\hline \multirow[t]{3}{*}{ Elements } & \multicolumn{10}{|c|}{ Type of fertilization } \\
\hline & \multicolumn{5}{|c|}{2014} & \multicolumn{5}{|c|}{2016} \\
\hline & C & NPK & MS & $B D$ & $M S+B D$ & C & NPK & MS & $\mathrm{BD}$ & $\mathrm{MS}+\mathrm{BD}$ \\
\hline $\mathrm{Zn}$ & $1.26^{c}$ & $0.80^{\mathrm{a}}$ & $1.02^{\mathrm{b}}$ & $0.95^{\mathrm{ab}}$ & $1.25^{c}$ & $1.21^{\mathrm{b}}$ & $0.86^{\mathrm{a}}$ & $1.61^{c}$ & $1.47^{c}$ & $0.97^{\mathrm{a}}$ \\
\hline $\mathrm{Cu}$ & $1.01^{c}$ & $0.64^{\mathrm{a}}$ & $0.55^{a}$ & $0.89^{b}$ & $0.54^{\mathrm{a}}$ & $0.81^{c}$ & $0.52^{\mathrm{b}}$ & $0.44^{b}$ & $0.98^{c}$ & $0.27^{\mathrm{a}}$ \\
\hline B & $0.26^{b}$ & $0.17^{\mathrm{a}}$ & $0.27^{\mathrm{b}}$ & $0.30^{\mathrm{b}}$ & $0.25^{\mathrm{b}}$ & $0.20^{\mathrm{b}}$ & $0.14^{\mathrm{a}}$ & $0.18^{\mathrm{ab}}$ & $0.20^{\mathrm{b}}$ & $0.14^{\mathrm{a}}$ \\
\hline $\mathrm{Sr}$ & $0.24^{c}$ & $0.18^{b}$ & $0.16^{\mathrm{b}}$ & $0.29^{c}$ & $0.08^{\mathrm{a}}$ & $0.28^{c}$ & $0.27^{c}$ & $0.20^{b}$ & $0.27^{c}$ & $0.10^{\mathrm{a}}$ \\
\hline $\mathrm{Cd}$ & $0.24^{c}$ & $0.14^{\mathrm{a}}$ & $0.22^{\mathrm{bc}}$ & $0.24^{c}$ & $0.21^{\mathrm{b}}$ & $0.24^{\mathrm{b}}$ & $0.09^{a}$ & $0.21^{b}$ & $0.24^{\mathrm{b}}$ & $0.22^{\mathrm{b}}$ \\
\hline $\mathrm{Mn}$ & $0.15^{\mathrm{a}}$ & $0.13^{\mathrm{a}}$ & $0.16^{b}$ & $0.15^{\mathrm{ab}}$ & $0.18^{\mathrm{b}}$ & $0.17^{\mathrm{b}}$ & $0.13^{\mathrm{a}}$ & $0.25^{c}$ & $0.19^{b}$ & $0.18^{b}$ \\
\hline Al & $0.14^{b}$ & $0.16^{\mathrm{b}}$ & $0.14^{\mathrm{b}}$ & $0.15^{\mathrm{b}}$ & $0.11^{\mathrm{a}}$ & $0.16^{\mathrm{b}}$ & $0.14^{\mathrm{a}}$ & $0.13^{\mathrm{a}}$ & $0.16^{\mathrm{b}}$ & $0.16^{\mathrm{b}}$ \\
\hline $\mathrm{Pb}$ & $0.16^{c}$ & $0.14^{c}$ & $0.11^{\mathrm{ab}}$ & $0.13^{\mathrm{bc}}$ & $0.09^{a}$ & $0.15^{c}$ & $0.13^{b c}$ & $0.10^{\mathrm{ab}}$ & $0.14^{c}$ & $0.08^{a}$ \\
\hline $\mathrm{Ba}$ & $0.16^{d}$ & $0.10^{\mathrm{b}}$ & $0.13^{c}$ & $0.14^{\mathrm{cd}}$ & $0.07^{a}$ & $0.10^{\mathrm{b}}$ & $0.06^{a}$ & $0.05^{a}$ & $0.10^{\mathrm{b}}$ & $0.04^{\mathrm{a}}$ \\
\hline $\mathrm{Ni}$ & $0.09^{a}$ & $0.09^{a}$ & $0.08^{a}$ & $0.14^{\mathrm{b}}$ & $0.09^{a}$ & $0.03^{a}$ & $0.05^{\mathrm{ab}}$ & $0.06^{b}$ & $0.05^{\mathrm{ab}}$ & $0.04^{\mathrm{ab}}$ \\
\hline Co & $0.08^{c}$ & $0.07^{b c}$ & $0.06^{b}$ & $0.11^{\mathrm{d}}$ & $0.04^{a}$ & $0.08^{b}$ & $0.08^{b}$ & $0.08^{b}$ & $0.15^{c}$ & $0.05^{a}$ \\
\hline $\mathrm{Cr}$ & $0.07^{c}$ & $0.05^{b}$ & $0.05^{b}$ & $0.08^{c}$ & $0.02^{\mathrm{a}}$ & $0.03^{c}$ & $0.02^{\mathrm{ab}}$ & $0.02^{\mathrm{ab}}$ & $0.02^{\mathrm{ab}}$ & $0.01^{a}$ \\
\hline $\mathrm{Fe}$ & $0.009^{c}$ & $0.005^{\mathrm{a}}$ & $0.008^{b c}$ & $0.008^{b c}$ & $0.006^{\mathrm{ab}}$ & $0.008^{a b}$ & $0.005^{a}$ & $0.006^{\mathrm{ab}}$ & $0.009^{b}$ & $0.005^{\mathrm{a}}$ \\
\hline Average & 0.30 & 0.21 & 0.23 & 0.27 & 0.23 & 0.27 & 0.19 & 0.26 & 0.31 & 0.17 \\
\hline
\end{tabular}




\section{Discussion \\ The impact of the factors on the yield, quality and nutritional value of wheat grain}

The increase in grain yield in the subsequent years was independent of the experimental conditions. This was caused by the plant rotation system (winter rapeseed-winter wheat-oats), in which following the harvest of all plants, their crop residues were left on the plot and plowed. It is likely that the nutrient content increased in the soil, and thus an increase in wheat yield was observed in the subsequent vegetative seasons.

The reasons for this pattern of yield structure can be seen in the sorption properties of MS. Clayey materials, to which MS belongs, have a relatively high capacity to sorb organic and inorganic compounds (Koutsopoulou et al. 2010, Jabłońska 2012). The application of MS or MS+BD may result in an improvement in the soil structure and reduce the leaching of minerals from the soil. Due to such characteristics, clay material content in MS may stabilize the processes of transformation of the compounds of fertilizers in the soil (especially $\mathrm{NH}_{4}^{+} / \mathrm{NH}_{3}$ derived from digestate). Moreover, application of MS increases water retention in the soil, which may in turn favorably affect the growth and development of plants during water deficit periods. This may explain the highest wheat yield after using MS+BD in 2014 and 2015.

The decrease in grain yield in 2016, compared to previous years, when fertilized by MS+BD, suggests the optimum time period in the use of tested materials is two years. The use of a third dose of MS+BD in the last study year probably disturbed the ion balance in the soil (excess of $\mathrm{P}$ and $\mathrm{K}$ ) and decreased the wheat yield.

The form and availability of $\mathrm{N}$ are considered to be the factors that most affect yield as well as protein and gluten content (López-Bellido et al. 2001, Lin et al. 2015). Mayer et al. (2015) found a significantly higher crude protein content ( $\left.180 \mathrm{~g} \mathrm{~kg}^{-1} \mathrm{DM}\right)$ in wheat fertilized with mineral fertilizers or mineral fertilizers in combination with organic fertilizers than in wheat fertilized with organic fertilizers, even at double rates, and in non-fertilized wheat (about $150 \mathrm{~g} \mathrm{~kg}^{-1} \mathrm{DM}$ ). In their research, wheat without fertilization was characterized by a significantly higher content of dry gluten (more than $120 \mathrm{~g} \mathrm{~kg}^{-1} \mathrm{DW}$ ) compared to the other fertilization treatments (about $100 \mathrm{~g} \mathrm{~kg}^{-1} \mathrm{DW}$ ). The differences in gluten content between the individual fertilization treatments were negiligble in the current study.

The yield of wheat also depend on the distribution of nitrogen doses over time and their amounts. According to López-Bellido et al. (2001), the rate of $150 \mathrm{~kg} \mathrm{~N}$ ha $^{-1}$ significant increased the protein content but did not significant increase the grain yield compared to the rate of $100 \mathrm{~kg} \mathrm{~N} \mathrm{ha}^{-1}$. The authors found that there were no significant differences in grain protein content between the three $\mathrm{N}$ rates studied, which they explained by the effect of variable weather conditions during cultivation in the individual years of the experiment. A greater effect of weather conditions on the content of major nutrients than the effect of the type and rate of fertilizers is also confirmed by the study of Mayer et al. (2015).

In the present study, the significantly higher protein and wet gluten content with digestate fertilization (2014) and MS+BD (2015 and 2016) may be due to the better timing of uptake of N by plants. Nitrogen from mineral fertilizer in the podzolic soil is freely available and probably is too quickly taken up to enhance vegetative growth of wheat. Increased intensity of the reversible sorption mechanisms (Taghizadeh-Toos et al. 2012) may explain the reduced losses and balanced consumption of $\mathrm{N}$ in all phases of plant development. This effect is confirmed by the higher harvest index after MS+BD application.

ChP of wheat grain ranged from 69.7 to $103.7 \mu \mathrm{g}$ of EDTA $\mathrm{g}^{-1}$ DW. For comparison, ChP of the grain of six spelt wheat cultivars can have a value ranging from 29.8 to 91.4 extract EC $_{50} \mathrm{mg} \mathrm{DW} \mathrm{ml}^{-1}$ (bound) (Gawlik-Dziki et al. 2012). In the study by Mazzoncini et al. (2015), the fertilization system (organic/conventional) did not significantly affect the antioxidant power (DPPH and ABTS) of white flour, whereas the antioxidant power in bran showed higher values under the organic system relative to the conventional system. The rate of fertilizer also has a significant influence on the antioxidant power. The results of Ma et al.'s (2015) study reveal that $\mathrm{N}$ fertilization at the rates of 180 and $240 \mathrm{~kg} \mathrm{ha}^{-1}\left(150 \mathrm{~kg} \mathrm{P}_{2} \mathrm{O}_{5} \mathrm{ha}^{-1} ; 150 \mathrm{~kg} \mathrm{~K}_{2} \mathrm{O} \mathrm{ha}{ }^{-1}\right)$ reduced the antioxidant activity of winter wheat grain compared to no fertilization. They observed higher antioxidant activity only after the application of $300 \mathrm{~kg} \mathrm{~N} \mathrm{ha}^{-}$ 1. Hung et al. (2011), as well as Okarter et al. (2010) analyzed the antioxidant activity of sprouted wheat grains and their phenolic content, and positive correlations between these parameters were found when whole wheat grains were investigated. The results of the present study also confirmed this, since the $\mathrm{ACl}$ calculated for each fertilization treatment in most cases coincides with the total phenolic content. 
A significant increase in the activity of antioxidant enzymes in the plant may also result from the defense mechanism induced in response to heavy metal stress (Belhaj et al. 2016) or disturbance of the ion balance in the soil. Indeed, the used variants of fertilization diversify phenolic content making it difficult to state clearly the mechanism of this phenomenon without additional tests concerning the level of oxidative stress markers as well as the activities of enzymes involved in phenolic synthesis and metabolism. But, from the nutritional point of view, these issues are important and lead to the conclusion that the most important factor is the final effect that can be generated by an improvement of antioxidant potential of wheat obtained in cultivation fertilized with BD and MS+BD (2014 and 2015) in relation to NPK and C. The successive decrease in ACl in the subsequent years after fertilization with $\mathrm{BD}$ and $\mathrm{MS}+\mathrm{BD}$ was probably influenced by either the introduction of excessive $\mathrm{K}, \mathrm{P}, \mathrm{Mg}$, and $\mathrm{Na}$ to the soil or a disturbance of the ionic balance in the soil.

\section{The impact of various factors on the accumulation of heavy metals in wheat grain}

The content of elements, including heavy metals, in a plant depends on many factors and their interactions. However, soil properties, which determine the bioavailability of these elements, are the main factor modeling the accumulation of elements in the plant (apart from its species). This study evaluated the effect of organic and mineral waste (MS, BD, and MS+BD) fertilization on the rate of uptake of heavy metals by winter wheat compared to control (without fertilization) and conventional fertilization (NPK).

Certain heavy metals, e.g. $\mathrm{Cd}, \mathrm{Cr}, \mathrm{Ni}$ and $\mathrm{Pb}$, can be found in high contents in fertilizer products processed from waste materials. On the other hand, Al, which is an abundant element in soil, increases the risk of Alzheimer's disease (Wang et al. 2016). The solubility of heavy metals can become problematic under conditions of acidic soils and low $\mathrm{Ca}$ and $\mathrm{Mg}$ content. Under such conditions, the heavy metal retention mechanisms in which the exchange of heavy metals with $\mathrm{Ca}$ and $\mathrm{Mg}$ occur, primarily surface precipitation, are disturbed (Melo et al. 2016).

The basic parameter regulating soil's ability to buffer is its $\mathrm{pH}$, and this is correlated to the redox potential (pE) and the content of $\mathrm{Ca}$ and $\mathrm{Mn}$ in the soil (Eshel et al. 2015). An increase in the accumulation of heavy metals is further linked to the mechanisms of plant physiology facilitating the uptake of elements under conditions of their deficiency in the soil (phosphorus and manganese in particular). A deficiency of macro- and micronutrients in soil results in the exudation of carboxylates and phenols by plant roots. These compounds increase the biological assimilation of nutrient elements, unfortunately also increasing the bioavailability of heavy metals (Clemens et al. 2002, Gherardi and Rengel 2004). Another mechanism of bioavailability changes of heavy metals is the activity of soil microorganisms related to soil parameters (e.g. pH, organic matter content) (Clemens et al. 2002, Jiang et al. 2008).

\section{Conclusions}

The results indicate that digestate and mudstone on a podzolic soil are not a significantly weaker nutrient sources to increase wheat yield compared to conventional mineral fertilization. In all years the co-application of wastes (MS+BD) increased the wheat grain yield compared to controls (significant differences) and in 2015 compared to NPK. In the third year, fertilization with MS+BD resulted in a non-significant decrease in wheat grain yield compared to NPK.In all years, BD and MS+BD fertilization increased the content of total protein, wet gluten, and phenols in wheat grain compared to NPK. Waste fertilization also had a positive effect on the total antioxidant capacity index $(\mathrm{ACl})$ of grain, but only in the first year. Three years' use of waste did not result in exceeding international norms for the heavy metal content in soil and grain. It is interesting to see that the concentration of the total content of heavy metals in soil as well as in the grains are lowest (with a few exceptions) in the digestate treatments. The calculation of the bioaccumulation index (BAI) demonstrated that NPK decreased BAI for $\mathrm{Zn}, \mathrm{B}, \mathrm{Cd}$, and Mn, whereas $\mathrm{MS}+\mathrm{BD}$ decreased $\mathrm{BAl}$ for $\mathrm{Cu}, \mathrm{Sr}, \mathrm{Pb}, \mathrm{Co}, \mathrm{Ba}$, and $\mathrm{Cr}$. These results suggest that digestate and mudstone can be an alternative to conventional fertilization, especially when used in combination (MS+BD). But, they can be used for up to two consecutive years. To confirm the test results and exclude the impact of other factors, research in this area should be continued.

\section{References}

Alburquerque, J.A., de la Fuente, C., Campoy, M.M., Carrascoa, L., Nájerab, I., Baixaulib, C., Caravacaa, F., Roldána, A., Cegarraa, J. \& Bernal, M.P. 2012. Agricultural use of digestate for horticultural crop production and improvement of soil properties. European Journal of Agronomy 43: 119-128. https://doi.org/10.1016/j.eja.2012.06.001 
Bahorun, T., Luximon-Ramma, A., Crozier, A. \& Aruoma, O.I. 2004. Total phenol, flavonoid, proanthocyanidin and vitamin C levels and antioxidant activities of Mauritian vegetables. Journal of the Science of Food and Agriculture 84: 1553-1561. https://doi. org/10.1002/jsfa.1820

Belhaj, D., Elloumi, N., Jerbi, B., Zouari, M., Abdallah, F.B., Ayadi, H. \& Kallel, M. 2016. Effects of sewage sludge fertilizer on heavy metal accumulation and consequent responses of sunflower (Helianthus annuus). Environmental Science and Pollution Research 23: 20168-20177. https://doi.org/10.1007/s11356-016-7193-0

Chen, R., Blagodatskaya, E., Senbayram, M., Blagodatsky, S., Myachina, O., Dittert, K. \& Kuzyakove, Y. 2012. Decomposition of biogas residues in soil and their effects on microbial growth kinetics and enzyme activities. Biomass \& Bioenergy 45: 221-229. https://doi.org/10.1016/j.biombioe.2012.06.014

Clemens, S., Palmgren, M.G., \& Krämer, U. 2002. A long way ahead: understanding and engineering plant metal accumulation. Trends in Plant Science 7: 309-315. https://doi.org/10.1016/S1360-1385(02)02295-1

Demirel, B., Göl, N.P., \& Onay, T.T. 2013. Evaluation of heavy metal content in digestate from batch anaerobic co-digestion of sunflower hulls and poultry manure. Journal of Material Cycles and Waste Management 15: 242-246. https://doi.org/10.1007/ s10163-012-0107-4

Eshel, G., Lin, Ch. \& Baninc, A. 2015. Novel approach for quantitatively estimating element retention and material balances in soil profiles of recharge basins used for wastewater reclamation. Science of the Total Environment 502: 517-525. https://doi. org/10.1016/j.scitotenv.2014.09.047

EU 2013. Commission Regulation (EU) No 1275/2013. The Official Journal of the European Union L 328: 86-92. http://extwprlegs1. fao.org/docs/pdf/eur129053.pdf

Gawlik-Dziki, U., Świeca, M. \& Dziki, D. 2012. Comparison of Phenolic Acids Profile and Antioxidant Potential of Six Varieties of Spelt (Triticum spelta L.). Journal of Agricultural and Food Chemistry 60: 4603-4612. https://doi.org/10.1021/jf3011239

Gawlik-Dziki, U., Świeca, M., Dziki, D. \& Sugier, D. 2013. Improvement of nutraceutical value of broccoli sprouts by natural elicitors. Acta Scientiarum Polonorum Hortorum Cultus 12: 129-140.

Gherardi, M. \& Rengel, Z. 2004. The effect of manganese supply on exudation of carboxylates by roots of lucerne (Medicago sativa). Plant and Soil 260: 271-282. https://doi.org/10.1023/B:PLSO.0000030182.11473.3b

Guo, J.T., Lee, H.L., Chiang, S.H., Lin, H.I. \& Chang, C.Y. 2001. Antioxidant properties of the extracts from different parts of broccoli in Taiwan. Journal of Food and Drug Analysis 9: 96-101.

Hung, P.V., Hatcher, D.W. \& Barker, W. 2011. Phenolic acid composition of sprouted wheats by ultra-performance liquid chromatography (UPLC) and their antioxidant activities. Food Chemistry 126: 1896-1901. https://doi.org/10.1016/j.foodchem.2010.12.015

Jabłońska, B. 2012. Sorption of phenol on rock components occurring in mine drainage water sediments. International Journal of Mineral Processing 104/105: 71-79. https://doi.org/10.1016/j.minpro.2011.12.008

Jiang, C.Y., Sheng, X.F., Qian, M. \& Wang, Q.Y. 2008. Isolation and characterization of a heavy metal resistant Burkholderia sp. from heavy metal-contaminated paddy field soil and its potential in promoting plant growth and heavy metal accumulation in metal polluted soil. Chemosphere 72: 157-164. https://doi.org/10.1016/j.chemosphere.2008.02.006

Johansen, A., Carter, M.S., Jensen, E.S., Hauggard-Nielsen, H. \& Ambus, P. 2013. Effects of digestate from anaerobically digested cattle slurry and plant materials on soil microbial community and emission of CO2 and N2O. Applied Soil Ecology 63: 36-44. https://doi.org/10.1016/j.apsoil.2012.09.003

Koutsopoulou, E., Papoulis, D., Tsolis-Katagas, P. \& Kornaros, M. 2010. Clay minerals used in sanitary landfills for the retention of organic and inorganic pollutants. Applied Clay Science 49: 372-382. https://doi.org/10.1016/j.clay.2010.05.004

Lim, J.E., Ahmad, M., Usman, A.R.A., Lee, S.S., Jeon, W.T., Oh, S.E., Yang, J.E. \& Ok, Y.S. 2013. Effects of natural and calcined poultry waste on $\mathrm{Cd}, \mathrm{Pb}$ and As mobility in contaminated soil. Environmental Earth Sciences 69: 11-20. https://doi.org/10.1007/ s12665-012-1929-z

Lin, Z., Chang, X., Wang, D., Zhao, G. \& Zhao, B. 2015. Long-term fertilization effects on processing quality of wheat grain in the North China Plain. Field Crops Research 174: 55-60. https://doi.org/10.1016/j.fcr.2015.01.008

Lopedota, O., Leogrande, R., Fiore, A., Debiase, G. \& Montemurro. F. 2013. Yield and Soil Responses of Melon Grown with Different Organic Fertilizers. Journal of Plant Nutrition 36: 415-428. https://doi.org/10.1080/01904167.2012.748062

López-Bellido, L., López-Bellido, R.J., Castillo, J.E. \& López-Bellido, F.J. 2001. Effects of long-term tillage, crop rotation and nitrogen fertilization on bread making quality of hard red spring wheat. Field Crops Research 72: 197-210. https://doi.org/10.1016/ S0378-4290(01)00177-0

Ma, D., Sun, D., Li, Y., Wang, Ch., Xie, Y. \& Guo T. 2015. Effect of nitrogen fertilisation and irrigation on phenolic content, phenolic acid composition, and antioxidant activity of winter wheat grain. Journal of the Science of Food and Agriculture 95: 1039-1046. https://doi.org/10.1002/jsfa.6790

Mader, B.T., Goss, K.U. \& Eisenreich, S.J. 1997. Sorption of nonionic, hydrophobic organic chemicals to mineral surfaces. Environmental Science \& Technology 31: 1079-1086. https://doi.org/10.1021/es960606g

Mayer, J., Gunst, L., Mäder, P., Samson, M.F., Carcea, M., Narducci, V., Thomsen, I.K. \& Dubois, D. 2015. Productivity, quality and sustainability of winter wheat under long-term conventional and organic management in Switzerland. European Journal of Agronomy 65: 27-39. https://doi.org/10.1016/j.eja.2015.01.002

Mazzoncini, M., Antichi, D., Silvestri, N., Ciantelli, G. \& Sgherri, C. 2015. Organically vs conventionally grown winter wheat: Effects on grain yield, technological quality, and on phenolic composition and antioxidant properties of bran and refined flour. Food Chemistry 175: 445-451. https://doi.org/10.1016/j.foodchem.2014.11.138 
Melo, L.C.A., Puga, A.P., Coscione, A.R., Beesley, L., Abreu, C.A. \& Camargo, O.A. 2016. Sorption and desorption of cadmium and zinc in two tropical soils amended with sugarcane-straw-derived biochar. Journal of Soils and Sediments 16: 226-234. https:// doi.org/10.1007/s11368-015-1199-y

Nazir, R., Khan, M., Masab, M., Ur Rehman, H., Ur Rauf, N., Shahab, S., Ameer, N., Sajed, M., Ullah, M., Rafeeq, M. \& Shaheen, Z. 2015. Accumulation of heavy metals ( $\mathrm{Ni}, \mathrm{Cu}, \mathrm{Cd}, \mathrm{Cr}, \mathrm{Pb}, \mathrm{Zn}, \mathrm{Fe}$ ) in the soil, water and plants and analysis of physico-chemical parameters of soil and water collected from Tanda Dam kohat. Journal of Pharmaceutical Sciences and Research 7: 89-97.

Ogundele, D.T., Adio, A.A. \& Oludele, O.E. 2015. Heavy Metal Concentrations in Plants and Soil along Heavy Traffic Roads in North Central Nigeria. Journal of Environmental and Analytical Toxicology 5: 334. https://doi.org/10.4172/2161-0525.1000334

Okarter, N., Liu, C.S., Sorrels, M. \& Liu, R.H. 2010. Phytochemical content and antioxidant activity of six diverse varieties of whole wheat. Food Chemistry 119: 249-257. https://doi.org/10.1016/j.foodchem.2009.06.021

Oyaizu, M. 1986. Studies on products of browning reaction antioxidative activities of products of browning reaction prepared from glucosamine. Japanese Journal of Nutrition 44: 307-315. https://doi.org/10.5264/eiyogakuzashi.44.307

Re, R., Pellegrini, N., Proteggente, A., Pannala, A., Yang, M. \& Rice-Evans, C. 1999. Antioxidant activity applying an improved ABTS radical cation decolorization assay. Free Radical Biology and Medicine 26: 1231-1237. https://doi.org/10.1016/S08915849(98)00315-3

Różyło, K., Gawlik-Dziki, U., Świeca, M., Różyło, R. \& Pałys E. 2016. Winter wheat fertilized with biogas residue and mining waste yielding and the quality of grain. Journal of the Science of Food and Agriculture 96: 3454-3461. https://doi.org/10.1002/jsfa.7528

Różyło, K., Oleszczuk, P., Jośko, I., Kraska, P., Kwiecińska-Poppe, E. \& Andruszczak, S. 2015. An ecotoxicological evaluation of soil fertilized with biogas residues or mining waste. Environmental Science and Pollution Research 22: 7833-7842. https://doi. org/10.1007/s11356-014-3927-z

Sudnitsyn, I.I. 2015. Effect of the size of elementary soil particles on the soil moisture characteristic curve. Eurasian Soil Science 48: 735-741. https://doi.org/10.1134/S1064229315050117

Svensson, K., Odlare, M. \& Pell, M. 2004. The fertilizing effect of compost and biogas residues from source separated household waste. Journal of Agricultural Science 142: 461-467. https://doi.org/10.1017/S0021859604004514

Świeca, M. \& Baraniak, B. 2014. Influence of elicitation with $\mathrm{H} 2 \mathrm{O} 2$ on phenolics content, antioxidant potential and nutritional quality of Lens culinaris sprouts. Journal of the Science of Food and Agriculture 94: 489-496. https://doi.org/10.1002/jsfa.6274

Świeca, M., Gawlik-Dziki, U., Kowalczyk, D. \& Złotek, U. 2012. Impact of germination time and type of illumination on the antioxidant compounds and antioxidant capacity of Lens culinaris sprouts. Scientia Horticulturae (Amsterdam Neth) 140: 87-95. https:// doi.org/10.1016/j.scienta.2012.04.005

Taghizadeh-Toos, I.A., Clough, T.J., Sherlock, R.R. \& Condron, L.M. 2012. A wood based low-temperature biochar captures NH -N generated from ruminant urine- $\mathrm{N}$, retaining its bioavailability. Plant and Soil 353: 73-84. https://doi.org/10.1007/s11104-011-1010-9

Violante, A., Cozzolino, V., Perelomov, L., Caporale, A.G. \& Pigna, M. 2010. Mobility and bioavailability of heavy metals and metalloids in soil environments. Journal of Soil Science and Plant Nutrition 10: 268-292. https://doi.org/10.4067/S0718-95162010000100005

Wang, Z., Wei, X., Yang, J., Suo, J., Chen, J., Liu, X. \& Zhao, X. 2016. Chronic exposure to aluminum and risk of Alzheimer's disease: A meta-analysis. Neuroscience Letters 610: 200-206. https://doi.org/10.1016/j.neulet.2015.11.014

Zhao, J. 2007. Nutraceuticals, nutritional therapy, phytonutrients, and phytotherapy for improvement of human health: a perspective on plant biotechnology application. Recent Patents on Biotechnology 1: 75-97. https://doi.org/10.2174/187220807779813893 